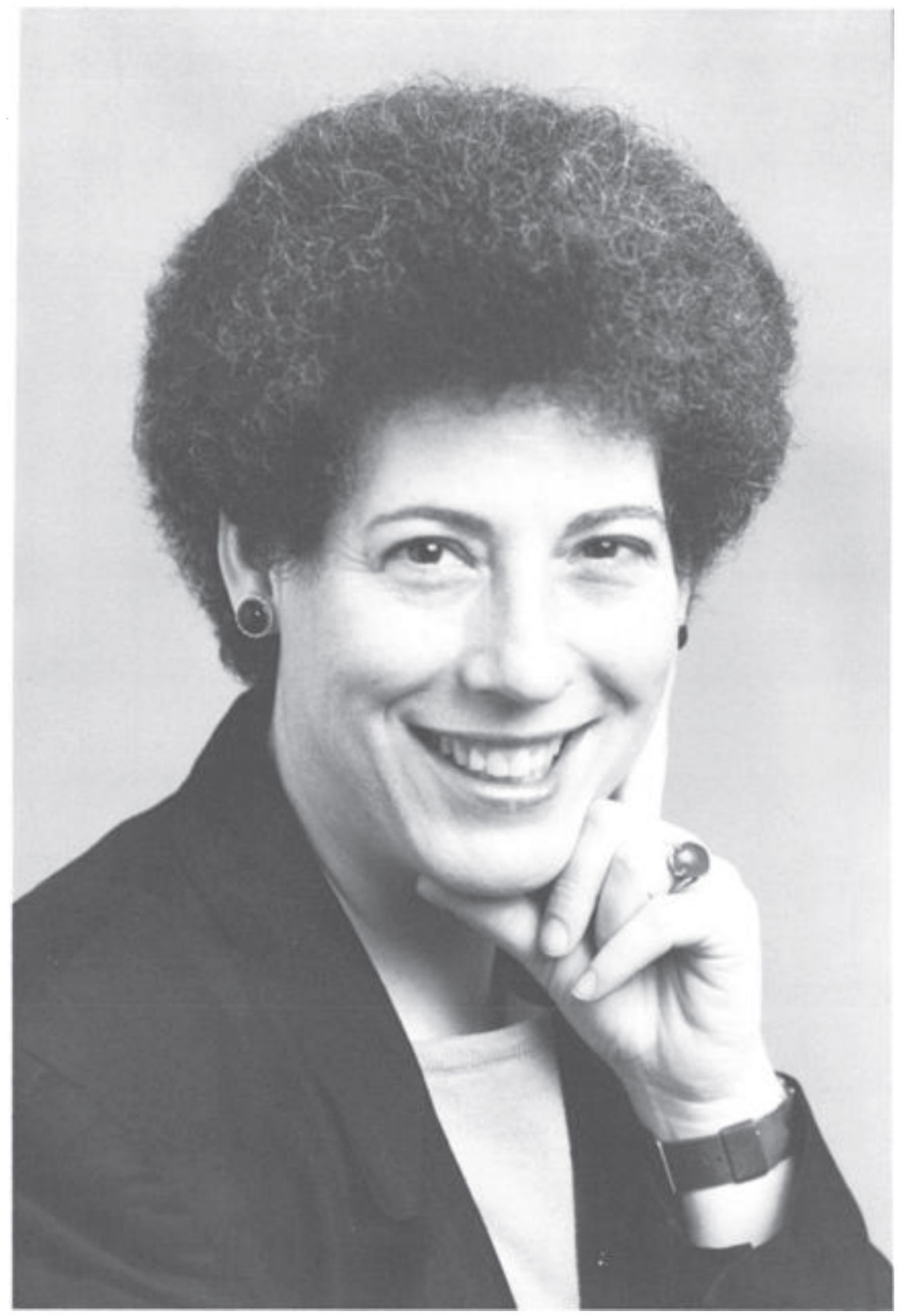

Fig. 1.1: Prof. Lizabeth Cohen, New York University. 


\section{A CONSUMER'S REPUBLIC: 'THE POLITICS OF CONSUMPTION IN POSTWAR AMERICA: AN INTERVIEW WITH LIZABETH COHEN}

\section{CONDUCTED BYLISA KANNENBERG AND LISA PHILLIPS}

Dr. Cohen, Professor of History, New York University, is the author of Making a New Deal: Industrial Workers in Chicago, 1919-1939 (New York: Cambridge Press, 1990).

The following interview entails a discussion of her current work in progress, an interdisciplinary study of the politics of consumption in postwar America.

Lisa Kannenberg and Lisa Phillips are pursuing doctoral degrees in the Department of History at Rutgers, The State University of New Jersey. Their areas of specialization include labor, social, and women's history.

Interviewee: Lizabeth Cohen (LC)

Interviewers: Lisa Kannenberg (LK) and Lisa Phillips (LP)

Place: $\quad$ Home of Lizabeth Cohen in Montclair, New Jersey

Date: $\quad$ May 5, 1995

LP: Perhaps we could begin by having you describe your earlier work, and how it led you in this new direction.

LC: As you know, my first book, Making A New Deal, was a book about workers in Chicago during the 1920s and 1930s. In that book I dealt with many issues. But I was particularly interested in the way that mass consumption, the consumer society, affected working-class Americans, particularly during the 1920 s, and how that carried over into their politics and political actions of the 1930s. One of my findings for the inter-war period was that despite what some stereotypes of the era suggest, workingclass people were not as integrated into the consumer culture as we think they were. Particularly in the 1920 s when installment buying and mass consumption and chain stores and so forth supposedly took off, workingclass people in many cases really weren't in an economic position to take advantage of much of that. They were living from payday to payday. They were laid off a lot of the time. They were living on the credit they got from the small corner grocer. I didn't find workers participating in this mass consumer society as expected. Then the Depression came in the thirties, and so I ended my book thinking that it was really going to be in the postwar period that those questions about the impact of a mass consumption society and workers' potential participation in a middle-class lifestyle would be an issue. So I ended feeling that those questions that we had assumed were 
going to be relevant to the inter-war period would probably be more relevant to the postwar period.

I love trying to figure things out for myself. And though there are plenty more questions to explore for the 1920s and 1930s, I felt that in a certain way I had worked them out for me, and I really wanted to move on from where I had left off. I left these people in 1939, and there was a world war coming, and a very different postwar society, and I really wanted to see what that was going to be like. But I've changed the venue. You know, it isn't going to be volume two of workers in Chicago.

LK: So what is the focus of your new work?

LC: I have tentatively entitled this book, "A Consumer's Republic: The Politics of Consumption in Postwar America." And I'm interested in how this mass consumer economy, society, and culture have shaped people's politics in the postwar period. I'm not, in this project, only concerned with working-class Americans. It becomes increasingly difficult to draw those lines anyway, as work becomes white collar, service-oriented. It gets harder to say what's white and what's blue collar. And so I have a broader reach in that sense. I'm continuing to look at the race question. In my previous book, as you know, I very much wanted to integrate the experiences of white and African-American people in one story, and I'm continuing to do that here.

Even though it's a national story, the way I have decided to limit the scope, is to situate it - when I need a stage set, and that is at certain moments and not at others-in the metropolitan New York area, with particular focus on northern New Jersey, because of the quintessential character of that region for postwar society. You know, here you see the classic postwar suburbs taking off in Bergen County. You see industrial cities like Newark and Paterson and Passaic in decline. You see the shopping centers that have really displaced downtown shopping booming in Paramus, the Garden State Plaza and the Bergen Mall being among the very first regional shopping centers. They opened in 1957. So it's all here, and it allows me to capture a population when I need a population to look at. Also, I can look at highway building which is crucial for the movement of people's residences and the shift in their workplaces from cities to suburban locales. New Jersey, the quintessential suburban state. So in some sense what I can see here-even though it's a small state-will probably be America writ large.

LP: What sort of themes or arguments are emerging at this point?

LC: Let me lay out to you the broad picture that I'm still very much shaping at this time because I'm in the midst of the research. I'm starting off with the argument that over the course of the 20th century, but particularly beginning in the 1930s and then through the war, there's a growing recognition that a healthy capitalist economy and an egalitarian American society—-the great promises of America-are dependent on mass 
consumption. Now, that's an idea that was obviously floated in the twenties but not in the same way. It's over the course of the thirties that padding the consumer's pocket becomes a way of getting us out of this depression. The war then contributes to that. And particularly as we look towards the end of the war, there's tremendous concern that the United States is going to be caught in another depression like after World War I. And the solution to reconversion, as you know, becomes the manufacture of consumer durables, and that means making mass consumption the center of the economy. So postwar prosperity would be fueled by consumer demand, and by an American public that is capable of, and interested in, consuming in that way.

But this is not just an economic solution. It's also a social and a cultural solution. The promise of a mass consumption society included the hope that this would be a way of reconciling capitalist growth with democratic commitments. So here the prosperity that was to come-and would, in fact, be relatively widespread in the fifties-promised not only to deliver an economic boom, but to draw people of various social classes and various races, who had been left out, into this large consuming public. More and more workers would become middle-class consumers. More and more Americans would become homeowners. The cultural message that equality is yours through consumption comes through in all of the ways that the mass consumer society operates: It operates through television, through advertising, through movies, through all kinds of media. So that's the promise and the hope. Historians have talked about it in terms of the Fordist solution ${ }^{1}$ of the postwar period, that workers would be paid more and would be drawn into a consumer middle class. They would not gain increasing power and authority in the workplace, and that compensation would be, instead, greater consumer participation.

LK: So how does race enter this postwar picture?

LC: I'm interested in the way in which the early civil rights movement in the forties and fifties promised blacks a kind of participation in this consumer society. The big struggle in the North coming out of the Second World War and through the fifties was to allow blacks to participate in public space, the battle over access to public accommodations. I'm looking at that in this metropolitan New York region and realizing how long it really took. It's quite astonishing how many struggles there were over being served in restaurants, using beaches and swimming pools, being able to go to skating rinks. It goes on and on. Equal rights on public transportation. You know, we think that these are battles only were fought in the South in the sixties, starting in ' 55 with the Montgomery bus boycott. We don't realize the extent to which these were not rights that blacks could assume they had in 
northern places like New Jersey. And I'm looking at this particularly in Newark because I want then to be able to follow the story through the sixties to the urban rebellions of ' 67 in Newark. What I think we lose when we look back at the early civil rights movement through the lens of a more militant sixties' civil rights movement, black nationalism, and so forth, is the extent to which in the forties and fifties it was really about participating as equals in a society where consumption was very much linked with citizenship. This is the promise anyway.

What I'm finding is that at the same time that this is going on, and certainly the expectation of it going on is there, crucial social re-segmentations are taking place at the same time. Suburbanization, for example, carried the promise of a new order where working-class people would live like middle-class people, and blacks would live like whites, and so forth. But in fact, as we know, it led to another whole era of residential segregation. There may have been a short time when in fact in these new suburban developments working-class and middle-class people lived side by side, given the housing shortages of the postwar period, but very quickly a kind of class segmentation developed. There's lots of complicated reasons for that that we probably can't discuss.

LK: So you find the urban neighborhood reproduced in the suburban neighborhood?

LC: Exactly. And in terms of race, I don't need to tell you how far we still have to go in terms of residential racial integration. The shift in marketplaces from downtown to shopping centers also contributes to a kind of segmentation of public space. I've done a chapter on this shift of marketplace from downtown to shopping center, and what I'm really watching here is a privatization of public space. Remember that this is moving from a downtown public square, or public street, to the privately-owned setting of a shopping center.

LP: And you have to drive.

LC: You have to drive there, so you have to have access to private transportation. And when you're there, your behavior is very much policed, who can be there is very much policed. Not always explicitly, but by location, by transportation access, and by the private guards and all the things that are involved in operating a private shopping center. We created a world in which there is segmentation in public space, not just in private space.

Then another aspect of this that I'm looking at is the political impact of this process that I see going on in the postwar period. And that is, by the 1960 s and 1970s, this new emphasis - the attention to the consumer and the role of mass consumption in the postwar world-does fuel a political movement to have the state regulate consumption more. And that leads to product safety legislation, truth-in-lending, -advertising, and -packaging, 
the drive for improved environmental quality, you know, the consumer movement as we know it. So that these expectations about the rights of the consumer, the way in which the consumer and the citizen become linked, does politicize people. And it does lead them to make new demands of government. But that is really in the short term. What I also am seeing happening in the long term is that ironically-and sort of tragically, I think-this politicization of people around their position as consumers reshapes people's relationships to the government in some of the ways that we're observing today. So that increasingly, people bring a consumer mentality to their relationship to government. They begin to judge government services as they would other goods and services that they purchase. So what we end up with, and I think what we're living with today, is a situation where as the public sphere eroded in the ways that I was laying out to you in terms of the privatized urban environment, and as the mass consumption economy began to falter beginning in the 1970s, people began defining their own interests more narrowly. And judging their relationship to the state as "consumer taxpayers" more than in terms of any larger public good. So that I think there's a change in the way people deal with government from, say, the thirties and forties when our welfare state emerges, to the eighties and nineties. And that helps explain, I think, much of the critical stance that many Americans-many voting and taxpaying Americans, anyway-have to government. They are viewing it from the vantage of being consumers. So that when it looked like the prosperity of the mass consumption economy had no limits, you know, in the fifties, we created a social world where we entrusted the marketplace with delivering freedom and justice for all. Now, as economic limits are more palpable, we are limiting freedom and justice in many ways to those consumers who can pay for them.

That's the sort of big picture that I am working on. And as I say, it will most likely change as I learn more.

LK: What collections at Rutgers have you drawn on?

LC: I've worked with collections in [Special Collections and University Archives located in] the main [Alexander] library, such as the Irma Angevine Papers. ${ }^{2}$ She was a consumer activist. And now I'm looking at the Consumers Research Papers [See Gregory L. Williams' article on Consumers Research Archives in this issue] and the International Union of Electrical Workers (IUE) Papers [See James P. Quigel's article on the IUE Archives in this issue]. Those two collections I was very fortunate to be able to use before they were really open to the public. Let's start with Consumers

\footnotetext{
${ }^{2}$ Erma Angevine Papers, 1957-1985, consisting of six cubic feet. Ms. Angevine was active in consumer affairs as an author, founder and first executive director of the Consumers Federation of America, Washington, DC, in 1968, and served as the president of the National Consumers League from 1977-1982.
} 
Research. For me, the Consumers Research Collection was extremely useful in a couple of ways. To start with, the main part of it that I used is a section called "Government War Preparation." Consumers Research's founder, Frederick Schlink, and his staff were obsessive newspaper and magazine article clippers, and these files are basically clippings and reports that they collected. I'm planning to write about the war and the way in which the war links consumer and citizen particularly for women on the home front. Because consumer issues were all over the place in wartime, Consumers Research collected huge amounts of material on the effect of war preparation on the consumer. The headquarters of Consumers Research was in Washington, New Jersey, the northernmost part of the state. And, because that's where they were, they had a particular interest in New Jersey.

The preponderance of material related to New Jersey made it doubly useful to me. There's a lot on the implementation of consumer regulation during the war, the OPA [Office of Price Administration] and its control over rationing, living with shortages and price controls, as well as the mechanisms that were set up to implement all that particularly on the New Jersey level. There's a lot of material on the consumer councils in the Newark area that were set up under the state and national governments. So I really could see how the government's role in regulating consumers and consumption in the war operated. And secondly, they were interested in the effects of this consumer regulation on consumers, and particularly on women. They went wild as the war came to an end, tracking the impact of the withdrawal of this regulation. I think that the immediate postwar period is really crucial. Because what I see going on then is a struggle between those who want the state to continue to regulate consumption through price controls, rent controls, you know, to set prices for meat, and so forth, and those who want the government to withdraw from that. And women and unions and other progressive organizations are very active in the struggle to keep the government involved and to protect people against enormous inflation. So there are big what they called "buyers' strikes" in 1946 and again in 1948. And the files contained a lot of documentation of that. The Consumers Research Collection is not so much valuable because it includes documents that you couldn't find anywhere else but because these people had a sort of tunnel vision around the consumer, and were hauling everything of relevance in. And so there it all was.

LK: Do you see that demand that government maintain its regulatory function as linked to what you described in Making a New Deal, the idea that people looked to government as an arbiter of justice, as a mechanism for social justice?

LC: Yes. The state hadn't been involved in this kind of regulation before, except to some extent, I guess, with banking. But this is a whole new arena. 
Wartime mobilization set up an entirely new function for the government. Of course there were a lot of inefficiencies and inequities in the way that the OPA operation actually worked. But still the whole rationale for the OPA, and for rationing, and for all the things that it regulated, was securing war supplies through equity and fairness. It wasn't fair for some people to go and hoard. It wasn't fair for people who had more money to be able to buy more. So there was a sense that the government was protecting, you know, the principle of equity and the survival of the little person. In fact this debate comes back again not very much later during the Korean War, which brings us to the IUE. The IUE plays a role along with other labor unions in pushing the government to do more regulating and to equalize the burden of wartime at the time of the Korean War. And there is this expectation and comparison back to World War II that that's what the government's supposed to do. Though I do think that it's gotten a lot more complicated. First of all, many more people are paying taxes. When I looked at debates in the thirties about the relationship of citizen to government, working-class people were rarely paying income taxes. During the war, the tax burden increases tremendously. By the end of the war withholding has been institutionalized. And the burdens of government are distributed in that way throughout the population. So I think people start to have expectations as citizen consumers of government services. In the 1950 to ' 52 debate over the role the government should play in regulating consumption, unionists say the tax burden is being carried too much by the working-class person, that corporations and wealthy people should be paying more.

Okay, back to Consumers Research. The other way that this collection was useful to me around wartime was that Schlink became, by the second half of the thirties, rabidly anti-Communist. When he had a strike in his own plant and the strikers went off and formed Consumers Union, he really went over the edge, and saw Reds everywhere. He and his clippers tracked anything that they thought was Communist-infiltrated, indicting many consumer organizations. Through that I discovered an organization called the League of Women Shoppers, which began in the mid-1930s and went until about 1947 or ' 48 , and then actually died as a result of charges by the Dies Committee. ${ }^{3}$ It was a left-leaning organization that Schlink and others felt was Communist-run, but it involved a lot of other people, including a lot of labor people. In some ways it was like the National Consumers League in having concerns around women as workers. But it also tried to mobilize people as consumers and to articulate the demands of consumers, particularly during the war.

LP: Was the League of Women Shoppers a national organization? 
LC: It was a national organization with headquarters in New York that had very active branches. I have material from the New Jersey branch, which was located in Newark. I also have material from other branches in the Harold Ruttenberg Papers that are at Penn State. He was involved with the Steelworkers, and his wife Kathryn was very active in the League of Women Shoppers. So I have a lot of material from there. Then there's some material up in Cambridge at the Schlesinger Library on the Washington branch, which I intend to look at. I don't know how big a role this organization will actually play, but-

LP: So did they target every woman as a consumer? Or did they target specifically working-class women?

LC: I can't tell you yet. But I think it was a progressive coalition that included middle- and upper middle-class women who were activists and reformer types, as well as people coming out of the labor movement and people coming out of the consumer movement. This material fits with the very earliest part of the book, where I'm looking at the thirties as a crucial time for recognizing the centrality of the consumer. We have focused as historians mostly on mobilization in the thirties around production and workers. But in fact, I'm discovering, there was a tremendous amount of mobilization around consumption. Certainly the first consumer legislation is passed in the progressive era, but there is another whole wave of it in the thirties. Consumer education really takes off in the thirties. There's another wave of the cooperative movement in the thirties. And not just among Finnish farmers and a certain kind of cultural radical. There were cooperatives in Harlem, for example, Ella Baker, who was crucial in the civil rights movement and who worked for the NAACP in New York in the forties, came to the NAACP out of consumer organizing in the thirties and early forties in Harlem. So there's a lot more politicization around consumption and unifying of people as consumers going on in the thirties than I think we realized. And war mobilization certainly builds on that.

The other thing I should just say about the Consumers Research Collection is that I was able to get material there on consumer boycotts all the way up through the 1970s. Whenever there were meat boycotts, grape boycotts, anything, they clipped it because they were interested in political activity built around consumers. So it was useful to me beyond the wartime.

LK: What are the parameters, or the time frame, of your book?

LC: It will begin with this early thirties and World War II chapter. But the heart of the book will be 1945 to about 1975, because I want to see the consumer movement heading downhill. The peak is in many ways under Kennedy and particularly Johnson. Nixon actually continues a fair amount of it but in a much different way as a Republican. It goes nowhere under Ford. Carter revives some of it. And then I'll probably have an epilogue which will cast ahead-Reagan obviously plays a very important role in 
redirecting people's relationship to government as critical consumers.

LP: We were wondering how you used the IUE collection, a standard labor archive, to talk about issues around consumerism.

LC: The IUE Collection, which I actually haven't done too much research in at this point, attracted me. I wanted to keep the working classes an issue in this book, and unions are a very good strategy for getting at working-class ideology, behavior, and so forth. The IUE was a very good case because it represents an industry that is clearly linked to the massconsumption economy and culture. This is an industry that's very much at the center of the production of consumer durables, which is the meat and potatoes of the mass-consumer society in the postwar period. It is a classic case of the reconversion from military to consumer durables. I think it's a good place to see workers at the vortex of production and consumption. What I have discovered already in doing some research in the collection is that the IUE, as one international, and workers where I can get at more of a grassroots level, were really quite aware of their dual power and vulnerability as producers and consumers. They realized they were both the producers of consumer durables and the buyers of what they produced.

This comes through, for example, in IUE-led boycotts of GE products in the early sixties; and in some very interesting material I've found related to a local of a Westinghouse lamp plant in Bloomfield, which is an industrial town not far from Newark. Let me back up a minute. I was looking for some union local material, and I was particularly interested in New Jersey, given my focus. And Jim Quigel [Rutgers University Libraries' Labor Archivist] located ten or 15 cartons of records that no one had even opened from Local 410, which was this Westinghouse lamp plant in Bloomfield. Additionally there was material from Local 420 which is the salaried workers. The collection includes mostly newsletters from 1942 to 1970 so that you really get a sense of what life was like on the shop floor and in the community. And here, for example-just to go back to the point I was making about workers' recognition of their dual role-workers were involved in lobbying local stores to carry Westinghouse products rather than GE products.

Most of the IUE collection I have seen is at the very sophisticated level of union administration, management, so forth. But where that is relevant to this project is the leadership's recognition that the industry's health, and therefore workers' health and workers' employment, depended on dynamic consumer demand and buying power. They very much recognized this crucial cycle. That comes through-I've seen it very well articulatedaround the Korean War, in their concern that consumer goods manufacturing is being limited by the burdens of military production. The IUE presses Congress on many fronts to keep the cycle going. For example, they push Congress to liberalize Federal Reserve Board regulations related to credit because they felt that more credit should be available so that working-class 
people-they called them lower-income people-can continue to purchase consumer durables so that they preserve jobs. But also so that they can continue to participate in the consumer society in the ways that they were promised. And they worry, as well, over inflation. They feel that high prices are going to penalize lower-income people more than wealthier people, that the standard of living will go down, that people won't be able to purchase, and that that will have an unfortunate cyclical effect.

When I first looked at this material, I wanted to test out the Fordist assumption that historians, economists and sociologists have put forth: That in the postwar period workers shifted their identities from being producers to being consumers, and that they bargained mostly around consumer kinds of demands rather than producer ones. The trade-off was that they got higher wages in return for less power on the shop-floor. My initial reaction is that that's just too simple. Plenty of shop-floor concerns continue. I'd like to hear from both of you what you have seen. I think it's really more viable to talk about the way in which workers recognized the intersection of their roles as producer and consumer. I really don't see people not caring anymore about what happens eight to four or whatever the work day is, and compensating with the house and the car, the simplistic sort of Fordist model that we have.

LK: Certainly in General Electric, the postwar period was filled with fights about shop-floor policy.

LC: I know. And then partly because GE is restructuring the workplace and launching a whole new set of welfare-capitalist strategies-the company keeps attention on those things, too.

LK: Yes. I've found that Fordism really doesn't work, at least not for the electrical industry and certainly not for General Electric. Because from the early fifties, the issues of job security are enormous, and there are continual debates over questions of automation and control of technology.

LC: Automation-It's there all the time, the issue of preserving jobs. But also continuing to care about the character, the quality, of those jobs. You just have to have blinders on, I think, to not see that. Because automation is not just about having those jobs. It's about what those jobs are.

To get back to electrical workers as consumers, another thing I have been able to find in the IUE Collection is IUE's involvement in the consumer movement. The union supports and has representatives on the board of the National Consumers League. In the late sixties when the consumer movement really takes off, and the Consumer Federation of America is founded after a big Consumer Assembly in 1968, the IUE is right there, along with other unions. In 1968 the IUE sets up an office of consumer affairs in the Department of Social Action. There's material that suggests that they recognize that quality of life, standard of living, can't be just viewed as a wage-labor issue. That it also is affected by consumption, by the consumer 
experience. So it's very clear that at that point, by the late sixties, unions like the IUE recognize the importance of the politics of consumption. It's a natural outgrowth of seeing their prosperity and their viability as dependent on this consumer economy. They start thinking we really need to protect the worker's experience as a consumer, not just producer.

There are a few other collections I've used here. Rutgers [Special Collections and University Archives] has been really very active in acquiring consumer-related collections. Along with the Consumers Research Collection, they have the papers of Irma Angevine and Sidney Margolius. ${ }^{4}$ Margolius was a very active consumer writer. He was very interested in consumer issues beginning in the 1940s and ' $50 \mathrm{~s}$. He was active in many consumer organizations, he wrote a newspaper column, he published books. The New Jersey Consumers League Papers also are at Rutgers; the national papers are in Washington. So there are actually a lot of collections nearby with a New Jersey focus, which is very nice for me.

LK: Does your work help to explain the stratification that is becoming glaringly apparent in post-cold war society?

LC: Well, that's really what it's about in many ways. There's a promise of equal participation and democratic egalitarianism that will come through the marketplace in this era of postwar prosperity. At the same time, however, a new kind of stratification happens as a result of that. People's expectation and the ability to purchase homes, for example, the whole explosion of suburbia, leads to new opportunities to segment. The whole shift in the locale of consumption, from downtown to regional shopping centers to cater to these new suburban populations stratifies marketplaces, and I think seriously threatens the public sphere. When shopping was still located in an urban downtown (though I wouldn't pretend that there wasn't a segmentation of retail institutions for different income groups), there still was a coming together in what were-no doubt about it-really public places and public spaces. When you move those public places, which are inevitably built around consumption in the postwar period, to those populations where they live, you end up with the situation we have today in northern New Jersey where you have retail oriented public places built around fairly well-off, middle-class consumer communities. And then you have a Newark and a Paterson with nothing. Absolutely nothing. In this chapter I track the total disappearance of department stores from downtown Newark, beginning in the sixties.

LP: I was wondering if you had any thoughts on those different communities and how they were affected by this process of segmentation. How did they voice their concerns? 
LC: Well, that's a question that interests me tremendously, and it is hard to get at. I hope to be able to answer that question for a range of the population. What I have been interested in looking at at this point is the ways in which blacks, who were in some ways most affected by this, expressed frustration in the mid-to-late sixties. Now, I'm not going to say that the urban rebellions of the sixties are about consumption. That's just too simple. They're certainly about police brutality, they're about housing conditions, the lack of services, the decline in public schooling, all of that. But one of the manifestations that one sees in every city that had a major riot was looting. And looting not just for destruction, but looting for consumption. I have lots of material where people, looters, are interviewed, and are very much after things that they want, such as televisions and living-room furniture sets. And what that says to me is not that you could cynically reduce African-American politics in the sixties to consumer desire. But that people had a sense of rights and entitlements that included being able to live a certain way in this society. That they didn't only define that by having a job. They saw that their full participation would be manifested in the quality of their life in a very concrete, material, way.

LK: Isn't that almost like a redefinition of citizenship in terms of consumption? It seems to subsume a lot of what we used to think of as citizen participation, so that rights are expressed in terms of consumption.

LC: Yes. This is one of the things I want to track. I think the war is critical in merging consumer and citizen, particularly for women, whose patriotic participation is really central in linking citizen and consumer. That's a very important theme that flows through this - the pivotal role of women in both shaping this order and challenging it. In the postwar order women are the chief household consumers. And when we look at the political mobilization around the rights of the consumer, women are there leading the consumer movement. That's where women are in the Kennedy and the Johnson White Houses. They're there as the consumer representatives. Consumer Advocate actually doesn't ever become a cabinet position, but it's close to that. And women are very high up in all these consumer organizations. But to go back to the question you're raising about citizenship and consumption. I don't want to over-argue it and say that the only way that one participates in the society as a citizen is as a consumer. But I do think that given what I'm trying to suggest about how the postwar world was supposed to workthat mass consumption was supposed to be a way, a vehicle, for equal economic participation-I think that that contributes to a sense of entitlement, that that's how one participates. Particularly as work changes in the postwar period, it becomes harder to say that it's your producer role that gives you a place in the sociery. When one increasingly lives in a service economy, where you're no longer a bricklayer or a carpenter, it's harder to place people based on their work. And increasingly, I think, people place 
themselves, and place other people, by their material surroundings and by their consumer capabilities. And so consumption becomes very important in social stratification, and in participation in that society. It's not the only way. People still do vote, though less and less, you know. But I do think consumption becomes an increasingly important way of participating in the society and culture. Then when it becomes a political movement, in the sixties and seventies, it does become a way of participating politically. Today the consumer has entered our vocabulary around many, many things. In the whole debate about health care, for example, it's a given that we talk about not the patient, but the consumer. And you can take any public policy debate, from welfare to social security, and we think about people as consumers. So we have certainly moved the word from the marketplace to the larger polity.

LP: Are there any other ways that women enter into your study, besides around questions of citizenship?

LC: Something very specific that I've been interested in is in the chapter I did on shopping centers. I found that in the shift from downtown to shopping centers, which is very dramatic in the 1950 s and 1960 s, department stores build branch stores and ultimately these become really the department store corporation. I've looked at the reaction of unions who had organized in Macy's, Gimbel's, and Stern's in downtown New York, all of whom had stores in the Paramus shopping centers. One union was just at Macy's and the other was organizing Gimbel's, Stern's, Bloomingdale's and some others. The unions see the move out to branch stores as basically a runaway shop. And they see that the success of their department store unions is really up for grabs because the department stores resist unionization in the branch stores. Not only do the stores resist it, but they change the whole structure of the labor force by hiring women as part-time sales people. They do much more self-service, putting more things out on the racks and whatever. But they also discover that they can save costs by hiring part-time, low-paid, and no-benefits women who live in the suburbs, who are looking for part-time work. I won't say that this isn't attractive to some of those women. But the solution that develops is one that keeps women in very dead-end employment because there's really no place to go from there; it's very exploitative. Women are the subject of interest, in that they are both the major consumers-the shopping centers, I show, are really designed for female consumers who will then direct their family consumption in a very specific way - and they are also staffing it.

LK: That's really interesting. Do you know what was the success of unions in going out and organizing those stores?

LC: Not very successful at all.

LK: The parallel then is really tight between this movement to the suburbs in the retail sector and industrial plants moving down South as industry decentralized. 
LC: Yes, exactly. For the same reasons.

LK: Yes. It's the same type of thing: the ability to reconstruct the workplace.

LC: And the work force. So we end up with a Newark that has neither plants nor stores but a lot of people still struggling to live there.

LK: In my work, I've been interested in the fate of those small merchants in the cities that often allied with workers, since their own interests were so dependent on workers' wages. Can you talk a bit about what happens to this sector of the business community in the move to the suburbs?

LC: You may remember that, in Making A New Deal, I saw those small merchants struggling during the Depression. And I think that small shopkeepers suffer a lot during the war with the whole price control issue. I haven't totally figured out the struggles over price controls. But there are differences of opinion between big retailers and small retailers. What I have seen that would be relevant to your question is that when-again, back to the shopping center and the downtown-when the locale shifts, the owners of the shopping centers have tremendous power over who's there in the shopping center. And they try to put together what they think is the perfect mix. They want limited competition between stores, they want a range of services and goods. They decide the most profitable locations for stores. And, increasingly, they want chains because the investors in shopping centers, who are entities like insurance companies with a lot of cash to invest, want a good return on their money. And they want the security of known quantities like chain stores. So that even when local businessmen and women want to make the shift to opening up in the mall, as small independents they face tremendous rents to start with. But they also are discriminated against because they don't have the kind of track record that the investors in this privatized downtown want. So there are these larger structural issues that I think cause tremendous change in the whole retail environment of the postwar period. These small merchants get caught in that. There's another thing that goes on that affects small business that's probably relevant to this-and that is the discount store emerges in the postwar period. It very much affects department stores and small merchants. A discount store like "Two Guys" is usually not in a shopping mall. It tends to be in the strip along the highways. It's open long hours, seven days a week, with very little sales help, and hence the prices are low. That pricing has to affect the small merchant.

LP: I was just wondering how the change from local businesses to shopping centers or downtown shopping centers, how the government is involved in this. In other words, is this shift being supported by the government?

LC: Yes, it's interesting. The standard statements we make about how the government aids in postwar suburbanization are built around the 
availability of home mortgage money through the GI Bill and the FHA, and federal subsidy of highway building. Now, I have seen some evidence, but I haven't really pinned it down, that there were tax advantages to new retail construction in contrast to renovating existing space, which ended up discouraging stores from investing in their downtown stores. But there were so many other issues involved, like the congestion of downtown. When lots of people started having cars, there wasn't adequate parking, there weren't adequate roads and streets. So there are so many things to sort out. It isn't just one direction, though. I looked at the efforts of old commercial industrial cities, say, like Paterson, to fight the malls. Paterson was always a strong commercial center, and now that it had lost its factories, retail had become increasingly important in the economy. But then you get these malls, and over a very short period of time the city loses a huge amount of dollars. Given the way the tax structure functions in New Jersey-it's so dependent on property taxes-the whole tax base was being destroyed in cities like Paterson. There was money available through urban renewal, through the various housing acts, to revitalize downtowns, not so much to build but to tear down; there was money to clear. So they did this whole awful, disastrous, downtown mall business in Paterson. They thought, well, if we replicate the mall, if we have the highways come right into downtown and have parking garages and make pedestrian walkways, we'll be competitive. They had a lot of money from the government to help do that. Well, I don't have to tell you how unsuccessful those efforts generally were. So there was government money because there were people pressuring in Washington. So I don't know that the incentives only went to dismantle downtowns.

But one of the things I'm looking at is not so much on the retail side as on the residential side. I've been doing a fair amount of research into the GI Bill and the impact of the GI Bill in creating this mass consumer world. I've been trying to figure out who took advantage of the mortgage programs and who took advantage of the education programs and in what way. And what I am finding is, again not surprisingly, a fair amount of segmentation in who and how people took advantage of GI benefits. There were some conferences that labor people in New Jersey held in the 1940s to assess the impact of the GI Bill, and they argued that it favored middle-class people who were going to college over working-class people who wanted to use the money for vocational training. It's all related to the way that the GI Bill operates. There aren't as many authorized places to take your benefits if you're not going to go to college, whereas this was a big boon for colleges. And the mortgagesIt turns out that the way that people got VA mortgages isn't the way I thought they got it. I thought you wrote to the government and you got your check. No. The money was all distributed through private banks, and the banks had to qualify people to get mortgages. So it turns out that many 
working-class people discovered that the banks wouldn't qualify them. And blacks-I did some research in the NAACP Papers in Washington-blacks wrote to the NAACP and said, "I can't get a mortgage. I'm being discriminated against." So because of the way we often filter government money through existing private institutions, it doesn't democratize in quite the ways that it promises. Now, I'm not saying that the GI Bill didn't make huge changes in the landscape of postwar America. Certainly people went to college who wouldn't have gone to college; people bought houses who couldn't have bought houses. But there were still limits on who had access. It's very interesting to see this going on. My first clue to this was in going through the NAACP Papers. I was looking at letters of complaint about discrimination in public accommodations. People were writing all the time and not just to make test cases. But to say, you know, I tried to go into a restaurant, or I had a meeting in New York and I couldn't stay at the hotel, or I-You know, it's just heartbreaking. You can't believe how people were still being treated, in the North, in the 1940 s and '50s. So I was looking at that material. And then I happened upon these letters complaining about the GI Bill.

LP: So you found that people's expectations weren't met? That the promise of the postwar order didn't materialize?

LC: Perhaps the irony, the tension, is around this tremendous rise in expectations. And to some extent, you know, there were certainly important changes. If the place of working-class people in the mainstream economy and society was limited in the 1920s and ' 30 s, it was less so in the ' $50 \mathrm{~s}$, ' $60 \mathrm{~s}$, and ' $70 \mathrm{~s}$. But the reality was different from the expectation and the ideology. America was still much more segmented than what this mass consumption postwar order promised.

LK: Given that continued segmentation, how did we develop the notion of the "universal middle class" that everyone identifies themselves as part of some homogeneous middle class?

LC: I would like to be able to answer that. I don't really know yet. I think it's a key question. One of the side effects of defining citizen, member of society, as consumer is that it is not class-based. It's liberal in that the focus is on the individual as consumer. It's not group-based. Yet I think it's possible that people can continue to have hyphenated identities. David Halle, the sociologist, makes that point in his book, America's Working Man (1984). He looks at working-class people in the late 1970s and finds that they're workers at work and middle-class people at home. He does argue that a lot of their identity rests as residents of communities, as consumers in a sense. I think that despite what we may want to think, people continue to live in this postwar period quite segmented by not just race, but also by class. When you build whole new suburbs around houses that are pitched to a certain price market, they artificially define that community. You know, so this is a community of houses that are a hundred to a hundred and fifty 
thousand dollars. And certainly there are old suburbs where you get a mix of people. Places like Montclair which is really a 19th-century, early 20thcentury suburb, where you have the old city mix of a tremendous range: racially, class-wise. But in the new suburbs that are farther out, they're really much more segmented, I think.

LP: Do you see that sense of hyphenated identity, of being working class at work and middle class at home, as in some sense a new version of the old "cooptation" theme? Were workers "duped"?

LC: There's always that edge to the Fordism argument, though it doesn't have to be. I mean one could say that this is a happy solution. But there is generally that tone that there's a kind of cooptation going on.

LK: False consciousness.

LC: Right. Exactly. And that workers should be more concerned about the quality of their collective lives. I don't know. I mean I'm always hesitant to take a moral position like that. Though you could argue that where I'm coming out certainly has a moral/political position built into it. If you take, for example, the issue of blacks and the riots-which I prefer to call rebellions-some people could look at that and be very critical of me and my interpretation, and then, potentially, of the participants as being sort of materialistic and not in fact acting out of more developed political ideology. But I think that's a very unrealistic and falsely superior position to take. Whereas, you know, people want to live lives that are defined as good lives in many ways. Some of that is spiritual, and some of that is social, and some of that is material. It's from the privilege of a well-off person that you would say that it doesn't matter to the quality of someone's life that they have some decent furniture and a television and a refrigerator and those kinds of things, because that's what we say to people are the signs of succeeding in this society, and those things make it easier to live. So I'm hesitant to make those kinds of judgments, to say that if you really want a refrigerator, you've been duped. I guess I'm being both more of a realist and being more respectful of what people do and their reasons for it. 
